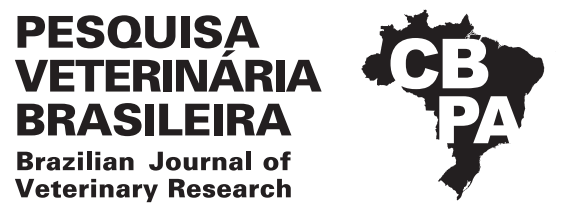

Pesq. Vet. Bras. 39(6):402-408, June 2019 DOI: 10.1590/1678-5150-PVB-6131

ISSN 0100-736X (Print)

ISSN 1678-5150 (Online)

\title{
Investigation of Norovirus genogroups (GI, GII and GIV) in stool of pet dogs with diarrhea ${ }^{1}$
}

\author{
Sevinc Sokel ${ }^{2}$ (D) and Mehmet Kale ${ }^{2 *}$ (D)
}

\begin{abstract}
Sokel S. \& Kale M. 2019. Investigation of Norovirus genogroups (GI, GII and GIV) in stool of pet dogs with diarrhea. Pesquisa Veterinária Brasileira 39(6):402-408. Departamento de Virologia, Faculdade de Medicina Veterinária, Mehmet Akif Ersoy University, Antalya Burdur Yolu, 15030 Yakaköy Köyü/Burdur, Merkez/Burdur, 'Burdur, Turkey. E-mail: drmkalex@yahoo.com

In this study, we searched the existence of human norovirus (NoV) GI, GII and GIV in the stool of 128 pet dogs with diarrhea, of different sex, age and breed, in Burdur, Turkey, using Real-Time PCR method. Human NoV GII was found in only 5 of the 128 dog stool samples (3.91\%). It was discovered that human NoV existed most in crossbreed, female and aged 24 months or over dogs. These dogs found with human NoV GII were either bought from pet shops, stray dogs or taken as puppy of another pet dog. The sheltering conditions of these dogs were moderate and they were fed with home food residue and dry food. It was also found that most of them were vaccinated and had certain walking sites. The owners of the animals detected with infection generally did not have the habit of washing their hands or changing their clothes before or after caring their pets. We strongly advice that dog owners' personal hygiene, the necessity of changing their clothes during their contact with animals, the environment provided for the dog, the sensitivity in caring, use of strong and effective disinfectant, keeping the dogs away from toilets and sewerage systems, as well as not feeding them with food residues are crucial issues in dogs' care. Owners of the dogs with NoV GII were middle aged or elderly people, male, and there were no children in their houses. As these dogs are treated like the owner's child, it is assumed that they could be transmitted with NoV GII as a result of close interaction with their owner.
\end{abstract}

INDEX TERMS: Norovirus, genogroups GI, GII, GIV, pet dogs, diarrhea, human, real-time PCR, stool.

RESUMO.- [Investigação de genogrupos de norovírus (GI, GII e GIV) nas fezes de cães de estimação com diarréia. ] Neste estudo pesquisamos a existência de norovírus humano (NoV) GI, GII e GIV nas fezes de 128 cães com diarréia, de diferentes sexos, idades e raças, em Burdur, Turquia, utilizando o método de PCR em tempo real. NoV GII humano foi encontrado em apenas 5 das 128 amostras de fezes de cães $(3,91 \%)$. Foi descoberta NoV humana, principalmente em cruzamentos, fêmeas e cães com idade igual ou superior a 24 meses. Os cães encontrados com NoV GII humano foram comprados de lojas de animais, eram vira-latas ou foram tomados como filhotes de outro cão de estimação. As condições de abrigo desses cães eram moderadas. Os cães foram alimentados com restos de comida

\footnotetext{
${ }^{1}$ Received on September 20, 2018.

Accepted for publication on February 16, 2019.

${ }^{2}$ Departamento de Virologia, Faculdade de Medicina Veterinária, Mehmet Akif Ersoy University, Antalya Burdur Yolu, 15030 Yakaköy Köyü/Burdur, Merkez/Burdur, Burdur, Turkey.*Corresponding author: drmkalex@yahoo.com
}

caseira e comida seca. Verificou-se também que a maioria dos animais foi vacinada e tinham locais adequados para caminhada. Os donos dos animais detectados com infecção geralmente não tinham o hábito de lavar as mãos ou trocar de roupa antes ou depois de cuidar de seus animais de estimação. Aconselhamos que a higiene pessoal dos donos, a necessidade de trocar de roupa durante o contato com animais, o ambiente fornecido para o cão, a sensibilidade no cuidado, o uso de desinfetantes eficazes, manter os cães longe de banheiros e esgotos, assim como evitar alimentá-los com resíduos alimentares, são questões cruciais no cuidado dos cães. Os proprietários dos cães com NoV GII são de meia-idade ou idosos, a maioria do sexo masculino, e não havia crianças em suas casas. Como esses cães são tratados como um filho, presume-se que eles foram infectados com o NoV GII como resultado de uma interação próxima com o proprietário.

TERMOS DE INDEXAÇÃO: Norovírus, genogrupo GI, GII e GIV, cães de estimação, diarreia, humanos, tempo real PCR, fezes. 


\section{INTRODUCTION}

Acute gastroenteritis (AGE) is seen all over the world in all age groups. A non-membraneous virus family, Caliciviridae, transmitted by fecal and oral ways, causes epidemic diseases. Norovirus (NoV) and Sapovirus from Calicivirus family are the most important viruses causing foodborne epidemic and AGE in all age groups (Rodriguez-Lazaro et al. 2012). NoV, which is very contagious, transmits from person to person by contaminated food and/or water and contact with contaminated surfaces. Particularly, symptoms of stomach ache, nausea-vomiting and diarrhea affect children and elderly people (Centre for Disease Control and Prevention 2017). NoVs have been reported to have been responsible for nearly $50 \%$ of AGE epidemics seen around the world. Zheng et al. (2006) standardized NoV strains genetically. With this study, they classified NoVs as strain, genotype and genogroup and detected 29 genotypes in 5 genogroups. GII was determined as the most common genogroup amongst studies on human NoV epidemics seen around the world. As a result of the studies conducted in late 1990s and 2001, NoV GII.4 was seen (White et al. 2002, Atmar \& Estes 2006, Bull et al. 2006). Like influenza virus, NoV also causes epidemics with new strains every 2-3 years (Turkey 2017). In studies performed from 2014 to 2015 epidemic seasons, human NoV GII.17 was reported to have caused natural infections with mutations in rhesus monkeys and probably been a new host (He et al. 2017). According to NoV phylogenetic research results, the new dominant NoV epidemic strain detected in AGE cases during 2016 winter season in European countries was reported as GII.P16-GII.2 (Niendorf et al. 2017).

NoV infection is effective in many animals such as calves, pigs, dogs, cats and monkeys other than humans. Gastroenteritis case is seen together with diarrhea in almost all cases (Karst et al. 2015). Canine NoV, genetically resembling NoV GIV in puppies with diarrhea, was reported in Italy (Pistoia) in 2006. Bari/170/07/ITA, a canine NoV prototype, was found 96.7\% similar to Pistoia/387/06/ITA lion NoV nucleic acid and $90.1 \%$ similar to amino acids of capsid proteins (Martella et al. 2008, 2011). Zoonotic disease factor of canine NoV reveals its potential depending on the facts that dogs have been living together with humans like a family member in recent years (the rate of dogs living in homes in England is 31\%) and there have been studies detecting that canine NoV uses the same receptors as human NoV while entering into the cell (Caddy et al. 2015, Karst et al. 2015).

There is not enough evidence about the zoonotic transmission of NoV between humans and animals. However, the fact that contamination of foods and environment by animal/human waste happens in indirect way leads to consideration of the agent as a zoonotic character. Studies detecting that human NoV and canine NoV use the same cell receptors make zoonotic risk possible (Karst et al. 2015, Rodriguez-Lazaro et al. 2012). The fact that animals are a crucial reservoir for human NoVs is a strong hypothesis. The study about the antibodies detected against human NoVs amongst pigs in Venezuela supports this case. However, although animal reservoir and zoonotic transmission is a known fact, difference between receptors and genetic distance does not support this case (Farkas et al. 2005).

In our study, we aimed to search the presence of NoV infection, which is a major public health problem, in possessed dogs showing diarrhea symptoms, to detect its genotype and to study nutrition and life conditions.

\section{MATERIALS AND METHODS}

\section{Dog stool samples}

In central Burdur (37 $\left.43^{\prime} 13^{\prime \prime} \mathrm{N}, 30^{\circ} 17^{\prime} 27^{\prime \prime} \mathrm{E}\right)$, stool samples were collected from 128 owned domestic dogs of various race and gender showing diarrhea symptoms kept in homes and gardens. Stool samples were stored in sample containers by the owners and brought to the lab under cold chain conditions by us. Stools taken from stool samples by sterile plastic spoon (nearly $1 \mathrm{~g}$ ) were removed into a glass tube were added by $5 \mathrm{~mL}$ RNAfter ${ }^{\mathrm{TM}}$ (GeneMark, GMbiolab Co., Ltd., Taichung, Taiwan) solution and vortexed for 5 min. Later, this mixture was kept in a $-20^{\circ} \mathrm{C}$ deep freezer until testing.

The owners were given a poll during collecting dog stool samples. The topics were as information about dogs (age, race, way of feeding, treatment for diarrhea and vaccination case), life conditions of the dog and presence of walking areas.

\section{Preparing dog stool samples for RNA extraction}

Stool samples collected under suitable conditions and kept in RNAfter ${ }^{\mathrm{TM}}$ solution under $-20^{\circ} \mathrm{C}$ were solubilized at ambient temperature. $1 \mathrm{~g}$ of stool from the solubilized mixture was taken by the help of sterile plastic spoon and was removed into previously prepared sterile eppendorf tubes. $1 \mathrm{~mL}$ Phosphate Buffer Solution (PBS) was added into these tubes. This new mixture in the eppendorf tube was vortexed for ten minutes. Later, the eppendorf tubes were centrifuged at $4^{\circ} \mathrm{C}$ at $2500 \mathrm{rpm}$ for $25 \mathrm{~min}$. After centrifugation, $0.25 \mathrm{~mL}$ of supernatants in the eppendorf tubes was taken into another sterile eppendorf tube.

\section{RNA extraction protocol in dog stool samples}

Homogenization. RNA extraction protocol was applied in order to detect virus genome in stool samples. 750 $\mu \mathrm{l}$ Trizol (GeneMark, GMbiolab Co., Ltd., Taichung, Taiwan) was transferred onto $250 \mu \mathrm{l}$ pretreated sample supernatant that was taken into eppendorf and was mixed by pipetation process. This mixture was centrifuged at $4^{\circ} \mathrm{C}$ at $978 \mathrm{x} g$ for 25 minutes.

RNA phase separation. $200 \mu$ l chloroform (Sigma-Aldrich Chemie GmbH, Steinheim, Germany) was added into sample and trizol mixture. After centrifugation at $4^{\circ} \mathrm{C}$ at $12000 \mathrm{x} g$ for $15 \mathrm{~min}$, organic molecules (cell proteins, DNA, lipid etc.) were taken into supernatant clean eppendorf tubes as RNA was located in the aqueous part in the sediment.

RNA precipitation. $500 \mu$ lisopropanol (Sigma-Aldrich Chemie $\mathrm{GmbH}$, Steinheim, Germany) was added in order to provide positive loading of RNA and precipitation. It was incubated at room temperature for $10 \mathrm{~min}$ and centrifuged at $4^{\circ} \mathrm{C}$ at $12000 \mathrm{xg}$ for $10 \mathrm{~min}$ and supernatant was poured. For washing, $1000 \mu \mathrm{l} 75 \%$ ethanol was added and mixed thoroughly and centrifuged at $4^{\circ} \mathrm{C}$ at $7500 \mathrm{xg}$ for $15 \mathrm{~min}$ and this process was repeated once. Supernatant was poured and left for drying. After drying, $40 \mu \mathrm{l}$ RNAase free water was added and incubated in the heater (Benchmark Scientific, Edison, New Jersey, USA) at $58.5^{\circ} \mathrm{C}$ for $15 \mathrm{~min}$. RNA extracted samples were stored at $-20^{\circ} \mathrm{C}$.

\section{Detecting NoV genome by Real-Time PCR}

In stool samples of domestic dogs, food proof ${ }^{\circledR}$ Norovirus Detection Kit-5'Nuclease-(BIOTECON Diagnostic ${ }^{\circledR}$, Potsdam, Germany) kits were used for detecting NoV GI, GII and GIV by Real-Time PCR method. Amplification stage was initiated by LightCycler ${ }^{\circledR} 480$ II Systems (Roche Diagnostics Ltd., Mannheim, Germany) device whose temperature-time program was set according to the determinants of the producing company of the 
kit. The data obtained by fluorescent reading in LightCycler ${ }^{\circledR}$ 480 II Systems device was evaluated according to the result evaluation table (Table 1) of the producing company of the kit.

\section{Statistical analysis}

Poll questions asked to dog owners were inserted into SPSS 15.0 (2007) statistical analysis program. Within the data, identifier analysis was carried out as frequency, average and standard deviation and was accepted as $\mathrm{p}<0.05$.

\section{RESULTS}

Samplings from different dog races were carried out for the study. The most frequent three races were Golden Retreiver (21.6\%), Shepherd's Dog (17.6\%) and Akbash-Kangal (11.8\%). $47 \%$ of the dogs were male and $53 \%$ was female. The dogs were 36.5 months old on average (minimum 1.0, maximum 156.0). The way of owning the dogs was classified as from pet shops, animal shelters, streets and private sources and those not included in these groups were stated as others. The most common way of dog owning was found as private sources (41.7\%, 53/128).

Dog owners evaluated the housing conditions as $6.7 \%$ bad, $42.3 \%$ moderate and 51\% good. In the poll applied in the study, the questions were on nutrition habits of the dogs, convenience dry food, home-made food, waste home food and as others and multiple options could be ticked. Correspondingly, participants claimed that $67.3 \%$ of the dogs were fed with convenience dry food, $66.3 \%$ with waste home food and $7.7 \%$ with home-made food. $51 \%$ of the dogs were stated as full-vaccinated, $30 \%$ as under-vaccinated and $18 \%$ as not-vaccinated $21.2 \%$ of the dogs had no walking area.

The average age of the dog owners was stated as 39.1 (minimum 12, maximum 69). $75.5 \%$ (97 persons) of the dog owners was male and $24.5 \%$ (31 persons) was female. When child presence was observed in dog-keeping houses, $49 \%$ (62 persons) was positive and 51\% (66 persons) was negative. The number of children living in dog-keeping houses was mostly two children at a rate of $58.8 \%$ (37 persons).

The household was responsible for caring the dog and multiple options could be ticked. Accordingly, the sequence was as $69.2 \%$ fathers, $41.3 \%$ mothers and $23.1 \%$ children. The average of the children living in the houses was found as $15.2+7.5,12.6+5.4$ and $10.8+5.2$ for the first, second and third child respectively.

In order to detect the behaviors and attitudes of people during contact for caring the dogs, four point likert scale prepared with the options "always, sometimes, rarely and never". $66.3 \%$ of the participants did not wash their hands before contact with the dogs and $60.6 \%$ of them had no habit of changing clothes. $62.5 \%$ of the participants had the habit of washing hands after caring the dog and $26.9 \%$ of them had no habit of changing clothes.

Human NoV GII was found in 5 of 128 dog stool samples examined by Real-time PCR (Fig.1). However, no positivity for NoV GI and GIV was found in samples with NoV GII. NoV GI, GII and GIV presence could not be detected in the

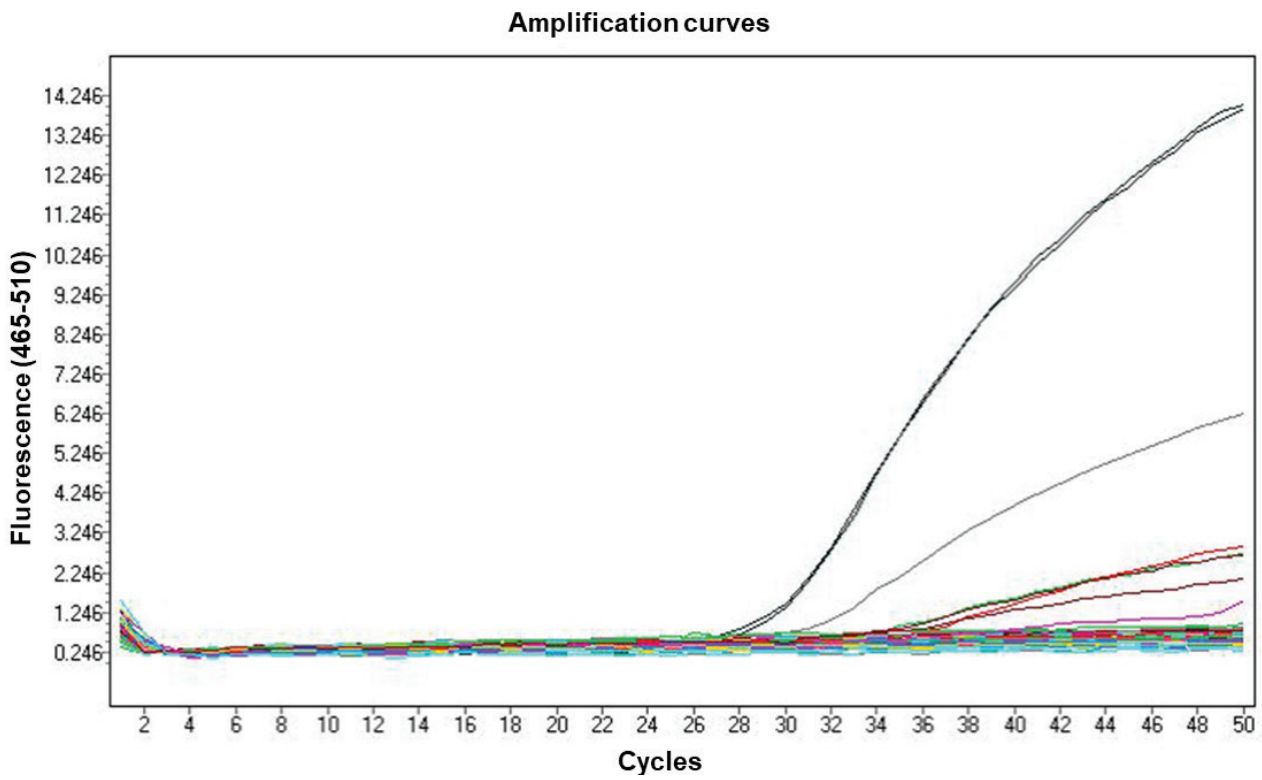

Fig.1. Real-time PCR results. PC1 = Positive Control 1 (CP:30.25), PC2 = Positive Control 2 (CP:30.07), S1 = Sample 1 (CP:33.20), S2 = Sample 2 (CP:39.92), S3 = Sample 3 (CP:40.52), S4 = Sample 4 (CP:39.48), S5 = Sample 5 (CP:42.76).

Table 1. Result evaluation table depending on the fluorescent wave length of HEX, FAM and ROX channels

\begin{tabular}{|c|c|c|c|}
\hline NoV GI HEX channel & NoV GII FAM channel & Proses Control ROX channel & Interpretations \\
\hline Positive & Positive & Positive / Negative & NoV GI and II/IV Positive \\
\hline Negative & Positive & Positive / Negative & NoV GII Positive \\
\hline Positive & Negative & Positive / Negative & NoV GI Positive \\
\hline Negative & Negative & Positive & NoV GI nd II/IV Negative \\
\hline Negative & Negative & Negative & Invalid \\
\hline
\end{tabular}


other 123 dog stool samples. The evaluation was performed using commercial kit result evaluation table according to the condition of fluorescent wave length of HEX, FAM and ROX channels.

The distribution of dogs detected as NoV GII positive was shown in Table 2. No diarrhea in the last 72 hours among the household (Table 2).

\section{DISCUSSION}

NoV is related with intestinal diseases of humans, sheep, pigs, mice and dogs. Canine NoV was first discovered in Italy in 2007. Later, during the studies carried out in Portugal, Greece and USA, it was found in dog stools (Caddy et al. 2014). Human NoVs are classified as GI, GII and GIV whereas canine NoVs are classified as GIV and GVI. Amino acid similarity is seen at a rate less than $85 \%$ between human and canine NoVs. Therefore they are divided into two different genotypes, IV.1 and IV.2 (Martella et al. 2009). Due to the facts that humans and dogs live together in close relationship, they share the same environment and this condition is highly common, the presence of human NoV in cat and dog populations has been searched by various studies. On the other hand, canine NoV antibody presence was detected for $22.3 \%$ of 373 vets dealing with small animal medicine and for $5.8 \%$ of 120 individuals (Mesquita et al. 2010).

Summa et al. (2012) used Real-time PCR method to detect NoV GI, GII and GIV presence in stool samples of owned dogs living in the same house with their owners. At the end of the study, human NoV presence was found in stool samples of four dogs in contact with humans showing diarrhea symptoms. Soma et al. (2015) searched for NoV presence in the stool of 97 dogs with diarrhea in Japan using RT-PCR. In the study, NoV presence was detected in two samples. Caddy et al. (2015) searched for human NoV presence in the stool samples of owned dogs in England using RT-PCR. They found human NoV antibody presence in 43 of $325 \mathrm{dog}$ blood samples. Di Martino et al. (2017) performed research by ELISA developed on the basis of human NoV GII.4, GIV.1 and dog NoV GIV.2 and GVI.2 like virus particles in $516 \mathrm{dog}$ blood serum. Mesquita et al. (2010) searched for NoV presence in 105 dog stools. In the study, diarrheal stools of 63 dogs and normal stools of 42 dogs were examined using RT-PCR. At the end of the examination, a new kind of NoV presence was detected at a level of $40 \%$ in stools of diarrheal dogs and $9 \%$ in stools of non-diarrheal dogs.
In our literature survey, we couldn't find a study on searching human NoVs in diarrheal dog stools. That's why our results are claimed to be the first from this aspect.

In this study, NoV GII was found in 5 (3.91\%) of $128 \mathrm{dog}$ stool samples. In these samples, no positivity was detected for NoV GI and GIV. NoV GI, GII and GIV presence could not be detected in 123 dog stool samples. Summa et al. (2012) stated that they found GII.4 in three and GII.12 in one of the positive samples particularly. Mesquita et al. (2010) tested blood samples of 308 dogs living in European countries against human NoV GI.1 and GII.4. In the study, 20 serum samples (19 GII.4 and 1 GI.1) showed positivity and 3.91\% rate of human NoV GII obtained from dog stools was parallel to $4.3 \%$ rate of human NoV GII obtained by Summa et al. (2012) from dog stools and to $2.2 \%$ rate obtained by Martella et al. (2009) for all NoVs in dog stools. However, during the studies were obtained higher prevalence results both in dog serum samples and in dog stools: 40\% (Mesquita et al. 2010), 11\% (Azevedo et al. 2012) and 10.1\% (Di Martino et al. 2017).

In Real-time PCR analysis in the study, we found Cp (Crossing point) values of the positive samples between the ranges of 33.20-42.76 (average 39.18). Summa et al. (2012) found $\mathrm{Cq}$ (Quantification cycles) values of the positive samples between the ranges of 23-37 (average 30.98) in Real-time PCR analysis. These results were close to each other. By the way, Ct (Treshold cycle), Cq and Cp expressions used in Real-time PCR define the same conditions with each other.

Summa et al. (2012) detected human NoV GII presence in 1 Irish setter, 1 Dachsund and two poodle races while Soma et al. (2015) detected that in 1 poodle and 1 Borzoi race. In this study, human NoV GII presence was detected in two crossbreed, 1 poodle, 1 golden retriever and 1 Rottweiler races. At the end of these three studies, Poodle race came into prominence. Human NoV presence was most seen in crossbreed race.

When infection was examined according to gender, Summa et al. (2012) detected distribution in three males and one female while Soma et al. (2015) found it in 1 male and one female. In the study, it was detected in one male and four females.

Mesquita et al. (2010) stated that the percentage of Canine NoV positive dogs rose until three years of age, decreased later and this condition depended on the decrease of immunity with aging. Summa et al. (2012) determined the distribution of age of dogs with human NoV GII as 1 for three year-olds, 2 for five year-olds and 1 for 6 year-olds. Soma et al. (2015)

Table 2. The results of NoV GII positive dogs

\begin{tabular}{|c|c|c|c|c|c|c|c|c|c|c|}
\hline No. & Breed & Gender & $\begin{array}{c}\text { Age } \\
\text { (months) }\end{array}$ & $\begin{array}{c}\text { Way of dog } \\
\text { owning }\end{array}$ & $\begin{array}{c}\text { Vaccination } \\
\text { condition }\end{array}$ & $\begin{array}{l}\text { Walking } \\
\text { area of the } \\
\text { dog }\end{array}$ & $\begin{array}{c}\text { Hand } \\
\text { washing } \\
\text { before } \\
\text { caring }\end{array}$ & $\begin{array}{c}\text { Clothes } \\
\text { changing } \\
\text { before } \\
\text { caring }\end{array}$ & $\begin{array}{c}\text { Hand } \\
\text { washing } \\
\text { after caring }\end{array}$ & $\begin{array}{c}\text { Clothes } \\
\text { changing } \\
\text { after caring }\end{array}$ \\
\hline 1 & $\begin{array}{l}\text { Golden } \\
\text { Retriever }\end{array}$ & Female & 40 & Stray dog & Full & Got & Rarely & Sometimes & Always & Sometimes \\
\hline 2 & Rottweiler & Female & 24 & Pet shop & Not & Got & Always & Sometimes & Sometimes & Sometimes \\
\hline 3 & $\begin{array}{l}\text { Miniature } \\
\text { Poodle }\end{array}$ & Female & 27 & Pet shop & Under & Got & Never & Never & Never & Never \\
\hline 4 & Crossbreed & Female & 30 & $\begin{array}{l}\text { Owned } \\
\text { puppy }\end{array}$ & Full & None & Rarely & Never & Sometimes & Never \\
\hline 5 & Crossbreed & Male & 36 & Stray dog & Full & None & Never & Never & Never & Never \\
\hline
\end{tabular}


detected NoV presence in two 2 month-old puppies. In our study, NoV presence was detected in 5 dogs whose average was 31.40 between 24.40 months. Di Martino et al. (2017) detected positivity from 7 to $9 \%$ in dogs younger than 1 year of age for NoV GII.4 and GVI.2 and 15\% in adult dogs older than 12 years of age. Different from these conditions, Caddy et al. (2015) stated that they could not detect human NoV presence in 131 dogs from 56 different races with 5.1 years of age range on average that were brought into vet clinics and in 117 healthy looking dogs with 5.6 years of age range on average.

In this study, it was realized that dogs detected with human NoV GII were obtained from pet shops as stray dogs and owned puppies. Their housing conditions were at medium level and they were fed with waste home food (60\%) and convenience dry food (100\%). 60\% was full vaccinated, $20 \%$ undervaccinated and $20 \%$ not vaccinated. $60 \%$ of the dogs had walking areas while $40 \%$ did not. $100 \%$ of the dogs with human NoV GII was diarrheal and had diarrhea treatment.

The average age of dog owners was 53.4 (minimum 36, maximum 62) and was classified in classes of middle-aged and elderly. The gender of dog owners was $80 \%$ male and $20 \%$ female. There were no children in houses with dogs. In contradiction to this condition, Summa et al. (2012) stated that little children lived in houses of positive detected dogs and that human NoV contamination from children to animals might be caused by uncontrolled vomiting of children onto surfaces and beds. In our study, $80 \%$ of fathers and $20 \%$ of mothers were responsible for feeding the dog. In dogs with human NoV GII, the fact that dog owners were classified in classes of middle-aged and elderly and were mostly male revealed that feeding and hygiene conditions were not satisfying.

Personal habit of hand washing of owners of dogs with human NoV GII before caring was stated with the rates as $40 \%$ rarely, $40 \%$ never and $20 \%$ always. The habit of clothes changing of owners before caring was found as $60 \%$ never and $40 \%$ sometimes. The habit of hand washing of owners after caring was stated with the rates as $40 \%$ never, $40 \%$ sometimes and 20\% always. The habit of clothes changing of owners after caring was found as 60\% never and 40\% sometimes. During the period when sampling was carried out, no diarrhea case was seen among the household in the last 72 hours. According to the data obtained here, owners of dogs with human NoV GII did not have the habits of hand washing and clothes changing before and after caring the dogs.

Human NoVs first need to bind complex carbonhydrates known as histo-blood group antigens (HBGAs) in order to enter cells (Marionneau et al. 2002). As in the case of erythrocytes, they are replicated at epithelial cell surfaces of gastrointestinal, genitourinary and respiratory system organs and HBGAs and are released by cells within body fluids including saliva (Marionneau et al. 2001). Human NoV agents were experimentally proved to enter cells by binding HBGAs. It was revealed that there is susceptibility between HBGAs replication and human NoV in gastrointestinal system (Lindesmith et al. 2003, Hutson et al. 2005).

Since human NoVs are sensitive to dogs, HBGAs replicate in gastrointestinal organs of dogs. Even though dog blood types do not resemble human systems, dog erythrocytes are not hemagglutinated by human NoVs (Hutson et al. 2003). For the time being, HBGAs production is visible in saliva and intestinal epithelial cell surfaces of dogs (Caddy 2017).
Contact is a crucial way of disease transmission from animals to humans or from humans to animals. During dog care, behaviors of individuals are important especially in terms of infections of zoonotic diseases. There is no sufficient data on zoonotic transmission of NoVs between humans and animals. However, some studies show that potential transmission is possible. Recent observations on canine NoV reveal that it uses the same cell receptors as human NoV and that transmission of animal NoVs to humans might be possible. Thus, the detection of anti-canine NoV antibodies by veterinarians is one of the examples showing this transmission (Karst et al. 2015). Besides, as the exact opposite of this condition, the detection of human NoV presence in stools of animals (cattle, pigs and dogs) is considered similarly (Peasey et al. 2004, Mattison et al. 2007, Caddy et al. 2015). It was stated that $45 \%$ of dog owners in America and Europe share their beds with their dogs and they might have zoonotic factors (Chomel \& Sun 2011). NoVs and other factors are said to transmit as a result of kissing their animals on the mouth or licking their owners by dogs (Chomel \& Sun 2011). Intense virus dispersion from stools of humans infected by NoV and vomiting that appears in acute phase of the infection is effective in transmission (Patel et al. 2009). Transmissions on surfaces inside or outside the house, unwashed dirty dishes, not using strong disinfectants in cleaning are crucial for dispersion of the factor (Weber et al. 2010). While dogs are walking outside, their furs, mouths, noses and paws are highly important in transmission of the factor to humans, animals and the environment (Summa et al. 2012).

In this study, dogs infected by human NoV are thought to have transmission by living spaces, environment, waste food and hand-mouth-body contact. Among the most important reasons, we reckon that especially toilets, sewerage systems, waste food by dog owners, home-environment walking areas and close contact between the dogs and their owners are in the foreground.

\section{CONCLUSIONS}

At the end of the study, human NoV GII was found in 5 (3.91\%) of 128 dog stool samples. No positivity for NoV GI and GIV was detected in samples with NoV GII. NoV GI, GII and GIV presence could not be found in the other $123 \mathrm{dog}$ stool samples. The obtained data was parallel to this kind of studies in recent years. This research seems to be the first study in our country in this manner.

Human NoV presence was mostly detected in crossbreed dog races, female dogs and dogs over 24 months old. Dogs with human NoV GII were obtained from pet shops as stray and owned puppies. Housing conditions of the dogs were at a medium level. They were fed with home food waste and convenience dry food. The majority had full vaccination and walking areas. $100 \%$ of the dogs with human NoV GII had diarrhea and diarrhea treatment.

Owners of dogs with human NoV GII often did not have the habit of hand washing and clothes changing before and after caring for the dog. Therefore, it is highly crucial to give importance to housing conditions, nutritional elements, living spaces, cleaning and hygiene conditions of dogs in their relation with the environment. Some basic precautions must be taken: personal hygiene of dog owners, the obligation to change clothes in contact with dogs, the environment prepared 
for the dog, the sensitivity in caring, usage of strong and effective disinfectants, keeping the dogs away from toilets and sewerage systems and not feeding them with waste food.

At the end of the study, the owners of dogs with human NoV GII were classified in middle-aged and elderly groups as mostly males and there were no children in these houses. Since it was estimated that dogs took the place of children as individuals in houses, it is natural that these dogs and their owners are in close contact (eating together, hugging, kissing etc.). In this regard, NoV GII, not seen in dogs by contact as a result of close relations of dogs and their owners, might possibly transmit from humans to dogs.

Acknowledgements.- This study has been supported by Mehmet Akif Ersoy University Coordinatorship of Scientific Research Projects with the project number 0358-YL-16.

Conflict of interest statement.- The authors have no competing interests.

\section{REFERENCES}

Atmar R.L. \& Estes M.K. 2006. The epidemiologic and clinical importance of norovirus infection. Gastroenterol. Clin. N. Am. 35(2):275-290. <http:// dx.doi.org/10.1016/j.gtc.2006.03.001><PMid:16880066>

Azevedo M., Mullis L., Vegas E., Britt J., Pereira O., Silva C. \& Vinjé J. 2012. Detection of norovirus in dogs in Arkansas. Proceedings of the 31st Annual Meeting of the American Society of Virology, Madison, WI, p.23-30.

Bull R.A., Tu E.T., McIver C.J., Rawlinson W.D. \& White P.A. 2006. Emergence of anew norovirus genotype II.4 variant associated with global outbreaks of gastroenteritis. J. Clin. Microbiol. 44(2):327-333. <http://dx.doi. org/10.1128/JCM.44.2.327-333.2006><PMid:16455879>

Caddy S., Breiman A., Le Pendu J. \& Goodfellow I. 2014. Genogroup IV and VI canine noroviruses interact with histo-blood group antigens. J. Virol. 88(18):10377-10391. <http://dx.doi.org/10.1128/JVI.01008-14> <PMid:25008923>

Caddy S. 2017. Can Noroviruses be zoonotic? Imperial College London, London, 4p. Available at <https://www1.imperial.ac.uk/resources/ DB493701-57D6-43A6-B369-B47BE72C6798/sarahcaddyswinningessay. pdf> Accessed on Apr. 18, 2017.

Caddy S.L., de Rougemont A., Emmott E., El-Attar L., Mitchell J.A., Hollinshead M., Belliot G., Brownlie J., Le Pendu J. \& Goodfellow I. 2015. Evidence for human norovirus infection of dogs in the United Kingdom. J. Clin. Microbiol. 53(6):1873-1883. <http://dx.doi.org/10.1128/JCM.02778-14> <PMid:25832298>

Centre for Disease Control and Prevention 2017. Norovirus. Available at <https://www.cdc.gov/norovirus/index.html> Accessed on Apr. Apr. 18, 2017.

Chomel B. \& Sun B. 2011. Zoonoses in the bedroom. Emerg. Infect. Dis. 17(2):167172. <http://dx.doi.org/10.3201/eid1702.101070><PMid:21291584>

Di Martino B., Di Profio F., Melegari I., Sarchese V., Massirio I., Palermo G., Romito G., Lorusso E., Lanave G., Bodnar L., Buonavoglia C., Marsilio F., Green K.Y. \& Martella V. 2017. Seroprevalence for norovirus genogroup II, IV and VI in dogs. Vet. Microbiol. 203:68-72. <http://dx.doi.org/10.1016/j. vetmic.2017.03.006 > <PMid:28619170>

Farkas T., Nakajima S., Sugieda M., Deng X., Zhong W. \& Jiang X. 2005. Seroprevalence of noroviruses in swine. J. Clin. Microbiol. 43(2):657-661. <http://dx.doi.org/10.1128/JCM.43.2.657-661.2005><PMid:15695660>

He Z., Liu B., Tao Y., Li C., Xia M., Zhong W., Jiang X., Liu H. \& Tan M. 2017. Norovirus GII.17 natural infections in rhesus monkeys, China. Emerg. Infect. Dis. 23(2):316-319.<http://dx.doi.org/10.3201/eid2302.161077> $<$ PMid:28102802>

Hutson A.M., Atmar R.L., Marcus D.M. \& Estes M.K. 2003. Norwalk virus-like particle hemagglutination by binding toHhisto-blood group antigens. J.
Virol. 77(1):405-415.<http://dx.doi.org/10.1128/JVI.77.1.405-415.2003> <PMid:12477845>

Hutson A.M., Airaud F., LePendu J., Estes M.K. \& Atmar R.L. 2005. Norwalk virus infection associates with secretor status genotyped from sera. J. Med. Virol. 77(1):116-120. <http://dx.doi.org/10.1002/jmv.20423> $<$ PMid:16032732>

Karst S.M., Zhu S. \& Goodfellow I.G. 2015. The molecular pathology of Noroviruses. J. Pathol. 235(2):206-216. <http://dx.doi.org/10.1002/ path.4463><PMid:25312350>

Lindesmith L., Moe C., Marionneau S., Ruvoen N., Jiang X., Lindblad L., Stewart P., LePendu J. \& Baric R. 2003. Human susceptibility and resistance to Norwalk virus infection. Nat. Med. 9(5):548-553. <http://dx.doi.org/10.1038/ nm860 > <Mid:12692541>

Marionneau S., Cailleau-Thomas A., Rocher J., Le Moullac-Vaidye B., Ruvoën N., Clément M. \& Le Pendu J. 2001. ABH and Lewis histo-blood group antigens, a model for the meaning of oligosaccharide diversity in the face of a changing world. Biochimie 83(7):565-573.<http://dx.doi.org/10.1016/ S0300-9084(01)01321-9><PMid:11522384>

Marionneau S., Ruvoën N., Le Moullac-Vaidye B., Clement M., Cailleau-Thomas A., Ruiz-Palacois G., Huang P., Jiang X. \& Le Pendu J. 2002. Norwalk virus binds to histo-blood group antigens present on gastroduodenal epithelial cells of secretor individuals. Gastroenterology 122(7):1967-1977.<http:// dx.doi.org/10.1053/gast.2002.33661><PMid:12055602>

Martella V., Lorusso E., Decaro N., Elia G., Radogna A., D’Abramo M., Desario C., Cavalli A., Corrente M., Camero M., Germinario C.A., Bányai K., Di Martino B., Marsilio F., Carmichael L.E. \& Buonavoglia C. 2008. Detection and molecular characterization of a canine Norovirus. Emerg. Infect. Dis. 14(8):13061308. <http://dx.doi.org/10.3201/eid1408.080062><PMid:18680664>

Martella V., Decaro N., Lorusso E., Radogna A., Moschidou P., Amorisco F., Lucente M.S., Desario C., Mari V., Elia G., Banyai K., Carmichael L.E. \& Buonavoglia C. 2009. Genetic heterogeneity and recombination in canine Noroviruses. J. Virol. 83(21):11391-11396. <http://dx.doi.org/10.1128/ JVI.01385-09><PMid:19710153>

Martella V., Pinto P. \& Buonavoglia C. 2011. Canine noroviruses. Clin. N. Am., Small Anim. Pract. 41(6):1171-1181. <https://doi.org/10.1016/j. cvsm.2011.08.002>

Mattison K., Shukla A., Cook A., Pollari F., Friendship R., Kelton D., Bidawid S. \& Farber J.M. 2007. Human noroviruses in swine and cattle. Emerg. Infect. Dis. 13(8):1184-1188. <http://dx.doi.org/10.3201/eid1308.070005> <PMid:17953089>

Mesquita J.R., Barclay L., Nascimento M.S.J. \& Vinjé J. 2010. Novel Norovirus in dogs with diarrhea. Emerg. Infect. Dis. 16(6):980-982. <http://dx.doi. org/10.3201/eid1606.091861> <PMid:20507751>

Niendorf S., Jacobsen S., Faber M., Eis-Hübinger A.M., Hofmann J., Zimmermann O., Höhne M. \& Bock C.T. 2017. Steep rise in Norovirus cases and emergence of a new recombinant strain GII.P16-GII.2, Germany, Winter 2016. Euro Surveillance 22(4):1-4. <http://dx.doi.org/10.2807/1560-7917. ES.2017.22.4.30447><PMid:28181902>

Patel M.M., Hall A.J., Vinjé J. \& Parashar U.D. 2009. Noroviruses: a comprehensive review. J. Clin. Virol. 44(1):1-8. <http://dx.doi.org/10.1016/j.jcv.2008.10.009> <PMid:19084472>

Peasey A.E., Ruiz-Palacios G.M., Quigley M., Newsholme W., Martinez J., Rosales G., Jiang X. \& Blumenthal U.J. 2004. Seroepidemiology and risk factors for sporadic Norovirus/Mexico strain. J. Infect. Dis. 189(11):2027-2036. <http://dx.doi.org/10.1086/386310><PMid:15143470>

Rodríguez-Lázaro D., Cook N., Ruggeri F.M., Sellwood J., Nasser A., Nascimento M.S., D’Agostino M., Santos R., Saiz J.C., Rzeżutka A., Bosch A., Gironés R., Carducci A., Muscillo M., Kovač K., Diez-Valcarce M., Vantarakis A., von Bonsdorff C.H., de Roda Husman A.M., Hernández M. \& van der Poel 
W.H. 2012. Virus hazards from food, water and other contaminated environments. FEMS Microbiol. Rev. 36(4):786-814. <http://dx.doi. org/10.1111/j.1574-6976.2011.00306.x> <PMid:22091646>

Soma T., Nakagomi O., Nakagomi T. \& Mochizuki M. 2015. Detection of Norovirus and Sapovirus from diarrheic dogs and cats in Japan. Microbiol. Immunol. 59(3):123-128. <http://dx.doi.org/10.1111/1348-0421.12223> <PMid:25545754>

Summa M., Von Bonsdorff C.H. \& Maunula L. 2012. Pet Dogs-A transmission route for human Noroviruses? J. Clin. Virol. 53(3):244-247. <http://dx.doi. org/10.1016/j.jcv.2011.12.014> <PMid:22244255>

Turkey 2017. Turkish Public Health Institution, Turkish Republic Ministry of Health. Bulaşıcı Hastalıkların Tanısı için Saha Rehberi. Available at <http:// mikrobiyoloji.thsk.saglik.gov.tr/ums/M-N/Norovirus-enfeksiyonu.pdf> Accessed on May 3, 2018.
Weber D., Rutala W., Miller M., Huslage K. \& Sickbert-Bennett E. 2010. Role of hospital surfaces in the transmission of emerging health care-associated pathogens: Norovirus, Clostridium difficile, and Acinetobacter species. Am. J. Infect. Control 38(5 Suppl.1):25-33. <http://dx.doi.org/10.1016/j. ajic.2010.04.196><PMid:20569853>

White P.A., Hansman G.S., Li A., Dable J., Isaacs M., Ferson M., McIver C.J. \& Rawlinson W.D. 2002. Norwalk-like virus 95/96-US strain isa major causeof gastroenteritis outbreaks in Australia. J. Med.Virol. 68(1):113-118. <http:// dx.doi.org/10.1002/jmv.10177><PMid:12210438>

Zheng D.P., Ando T., Fankhauser R.L., Beard R.S., Glass R.I. \& Monroe S.S. 2006. Norovirus classification and proposed strain nomenclature. Virology 346(2):312-323. <http://dx.doi.org/10.1016/j.virol.2005.11.015> <PMid:16343580> 